\title{
Habitat Improvements with Wildlife Purposes in a Grazed Area on the Apennine Mountains
}

\author{
Maria Paola Ponzetta* ${ }^{* 1}$, Francesco Cervasio $^{2}$, Chiara Crocetti ${ }^{1}$, \\ Alessandro Messeri², Giovanni Argenti ${ }^{3}$ \\ ${ }^{1}$ Dipartimento di Biotecnologie Agrarie, Sezione Scienze Animali, Università di Firenze, \\ Via delle Cascine 5, 50144 Firenze, Italy \\ ${ }^{2}$ CIRSeMAF, Università di Firenze, Via Maragliano 77, 50144 Firenze, Italy \\ ${ }^{3}$ Dipartimento di Scienze delle Produzioni Vegetali, del Suolo e dell'Ambiente Agroforestale, Sezione Scienze \\ Agronomiche e Gestione del Territorio, Università di Firenze, Piazzale delle Cascine 18, 50144 Firenze, Italy
}

Received: 14 September 2009. Accepted: 18 December 2009.

\begin{abstract}
In many European countries, the abandonment of traditional practices in the last decades produced remarkable effects on agricultural land use. In marginal mountain lands, one of the most evident outcomes is the reduction of the surfaces occupied by open habitats, mostly represented by meadows and pastures. The ecological consequences of reduced grazing in the pastures concerned not only the vegetation structure but also the floristic composition and the biodiversity of the herbaceous component, which is modified by the progressive establishment of woody species. For these reasons, it is important to carry out specific programs of habitat improvements in order to restore and maintain herbaceous vegetation, both for faunistic purposes and biodiversity conservation. In this note we describe the effectiveness of agronomical intervention carried out to enhance pasture quality in a protected area, once grazed by domestic animals, now utilised exclusively by wild fauna. The study was carried out for five years in a Regional Park (Parco Regionale dei Laghi di Suviana e Brasimone, Emilia Romagna, central Italy), in an experimental area where the vegetation was characterised by a high presence of bracken fern. Agronomical operations consisted of the restoration of a pasture, using an appropriate forage mixture. After the restoration, data collection concerned botanical composition, floristic richness and biodiversity of vegetation. Moreover, the utilization of single species by wild fauna was assessed by means of the defoliation rate methodology in order to evaluate the real consumption of each plant species. The results obtained in the studied area confirmed the efficiency of the improvement in terms of botanical composition and pastoral value of the pasture and they provided detailed information about selection of different plant species by wild ungulates.
\end{abstract}

Key-words: defoliation rate, pastures, botanical composition, wild ungulates.

\section{Introduction}

The abandonment of agricultural activities after the Second World War has gradually assumed great importance in the hilly and mountainous areas. Pastoral activity has been one of the sectors mainly affected by abandonment of land and extensification of the less productive areas (Didier, 2001; Mayer et al., 2006; Peeters, 2008; Van den Pol-van Dasselaar et al., 2008). One of the most observable consequences of land abandonment is the reduction of open surfaces located in marginal areas, like meadows and pastures once intensively utilised by domestic ani- mals (Messeri et al., 2007), but which are now subjected to the diffusion of shrubs and undesirable plants (Lombardi et al., 2001). This progressive "closing" involved the reduction of biodiversity, highly affected by presence of woody species (Rook and Tallowin, 2003) and the reduction of the heterogeneity of landscape (Laiolo et al., 2004). Moreover, the presence of woody species encroaching pastures not only reduces grazing surface but also negatively affects many important characteristics of herbaceous resources, as productivity, quality of the forage and carrying capacity (Lombardi, 2005; Dzwonko and Loster, 2007; Zarovali et al., 2007). 
The great ecological value of the open areas includes the presence of ecotone, the transition area between two adjacent but different plant communities, such as forest and grassland, characterized by a significant increase in number of species (Silver et al 2000; Argenti et al., 2000). This vegetational complexity attracts animals which choose these zones as feeding and reproduction sites. During the process of secondary succession, following the abandonment of agro-pastoral practices, the most ecologically specialized plant species tend to disappear in favour of the more competitive ones, and this process can reduce the suitability of the area both for domestic and for different kinds of wild animals (Pain and Dixon, 1997). This situation progressively lead to a strong reduction of plant biodiversity with a rapid loss of endemic species and a decrease of geophytes plants in the herbaceous association, with a consequent simplification of flora and the vegetation in pastoral areas no longer used (Staglianò et al., 2003).

The conservation and correct management of wildlife must be done through the maintenance of forest structure and of its coverage, to encourage the presence of ungulates and to put them in conditions to cause very limited damages. Furthermore, maintaining a balance between forest and open areas is essential for biodiversity conservation.

The presence of pasture areas far from cultivated fields is an important item to optimize the management of ungulate species, resulting in a reduction of damage to agricultural crops (Danilkin, 1996). This aim has been addressed in recent years in many areas on the Apennine Mountains through the implementation of programs to improve the environment in order to maintain the carrying capacity for large ungulates (Cervasio, 2009). This context includes a research project carried out on a protected area in central Italy with the purpose to evaluate the possibilities for the control of bracken fern (Pteridium aquilinum (L.) Kuhn), a particularly invasive species that can cause a rapid decline of open habitats in the marginal areas of the hills and mountains (Pakeman and Marrs, 1992; Le Duc et al., 2000).

Preliminary results have confirmed that this plant depresses considerably the diversity of flora and the pastoral value of the food resources for local fauna (Cervasio et al., 2008), making the infested areas overly homogeneous and poor (Ouden, 2000). In this work we consider the evolution of vegetation and the ecological characteristics in an open area subjected to environmental improvement programs directed towards the increase of biodiversity, floristic richness and of the palatability value of vegetation for wild ungulates that may use the recovered pasture.

\section{Materials and methods}

The area of study, called "Monte Calvi", was located inside the "Parco Regionale dei Laghi di Suviana e Brasimone" in the northern Apennine Mountains (Emilia-Romagna, central Italy), at about $1100 \mathrm{~m}$ a.s.l. The area was 10 ha wide, for the most part flat and with a prevalent east exposure. A program of pasture restoration took place in this area in 2003 in order to deal with a massive presence of invasive vegetation (mainly represented by $P$. aquilinum). Inside the area, all invasive vegetation was cut up by means of a tractor and then ploughed at a minimum depth of $15 \mathrm{~cm}$. A mixture of forage species suitable to the specific pedo-climatic conditions of the area was then sown. The mixture species were (in brackets the percentage presence by weight): Bromus inermis Leyser (30\%), Dactylis glomerata L. (30\%), Festuca ovina L. (25\%), Trifolium pratense L. (10\%) and Lotus corniculatus L. (5\%). In the following two years the sward was cut once a year to maintain the new vegetation. The effect of mowing has somewhat simulated grazing or mowing of hay that once was carried out regularly in these areas. During the summer months from 2003 to 2008 data concerning the cover of bracken fern and botanical composition were collected, taking four samples monthly, using the linear analysis method according to Daget and Poissonet (1969).

This survey permitted the determination of the specific contribution (SC) of each species within the total of recognised vegetation, through which the pastoral value (PV) was calculated using the formula $\mathrm{PV}=\Sigma\left(\mathrm{SC}_{\mathrm{i}} \times \mathrm{SI}_{\mathrm{i}}\right) / 5$, where $\mathrm{SI}$ is a specific index, variable from 0 to 5 , which summarizes the potential value of each forage species (Cavallero et al., 2002; Roggero et al., 2002).

Furthermore, utilising the results of linear analysis, biodiversity was estimated by the Shannon-Wiener index: $\mathrm{H}^{\prime}=-\Sigma \mathrm{p}_{\mathrm{i}} \ln \mathrm{p}_{\mathrm{i}}$, where $\mathrm{p}_{\mathrm{i}}$ is 
the percentage of the specific frequency in decimal fraction (Magurran, 2004). The floristic richness ( $\mathrm{R}$ ) was also assessed by the average number of species occurring along the transects.

To analyze the direct impact of wild animals browsing different species, the defoliation rate (DR) was recorded in the last two years of surveys, according to Jouglèe and Dorèe (1987). This method provides, through the recognition of the actual level of utilisation on the vegetation along the transect lines, the assessment on the effective proportion of grazing on each species recorded in the linear analysis. The data on vegetation collected observing the defoliation rate of the plants grazed is therefore the only way to determine the actual use of pasture by the wild ungulates and to know which species are in reality used by animals. The palatability was assessed using the method of the "contribution to the defoliation rate", proposed by Orth et al. (1998). This method states that the ratio between the defoliation rate obtained and the percentage of the presence of the same species in the sward indicates whether the species is highly sought by animals (ratio greater than 1) or if the rate of collection is in line with the percentage of the species within the pasture, so that each species is used in proportion to its presence (ratio equal to 1 ).

Data collected during the different years of trial were analysed by ANOVA using the following linear model (SAS, 2003):

$$
\begin{gathered}
\text { Yij }=\mu+\mathrm{Ai}+\mathrm{Eij}, \text { where } \mu=\text { mean; } \mathrm{A} \\
=\text { year; } \mathrm{E}=\text { error. }
\end{gathered}
$$

\section{Results and discussion}

A marked reduction of fern is clearly observable in table 1 , where the almost total disap- pearance of Pteridium aquilinum after the agronomical operations is highlighted. At this time the infestation can be considered eliminated, thanks to the removal of rhizomes during ploughing. The cuts, regularly performed in the early years, have prevented the re-entry of $P$. aquilinum. Values show that the mixture established well, however since 2006 the re-growth of native species has strongly increased. This can be related to the lack of agronomical management, in particular of the cuts in the final stage of the trial, that partially undermined the best botanical composition obtained and resulted in a reduction of the botanical families of fodder interest (legumes and grasses), while species belonging to other botanical families (not seeded intentionally) showed a strong tendency to establish themselves along time.

Before the agronomic management took place, the massive presence of bracken fern oppressed the underlying plants, and had certainly limited the emergence of families of forage interest such as legumes, typically considered heliophilous plants. In the three years following the agronomical management plan there was a substantial increase in the presence of palatable species; grasses, in particular, were favoured by cuts carried out in 2004 and 2005. After this period, however, the small utilisation of the pasture produced a slight decrease of grasses and legumes and a significant increase in native species. These species, limited in their spread in the first years through proper mowing, have generally shown a reduced or sometimes absent values of specific index. In consequence of this, the total pastoral value of the open area moves from the high value of 44 (just after the environmental restoration) to 25 at the end of the study period.

Table 1. Evolution of specific contribution (\%) of mixture species (SCM), spontaneous species (SCS), grasses (SCG),

\begin{tabular}{|c|c|c|c|c|c|c|}
\hline & 2003 & 2004 & 2005 & 2006 & 2007 & 2008 \\
\hline SCM & - & $78.2^{a}$ & $56.5^{\mathrm{b}}$ & $46.6^{b}$ & $26.4^{c}$ & $20.4^{d}$ \\
\hline SCS & - & $21.8^{\mathrm{e}}$ & $43.5^{\mathrm{d}}$ & $53.4^{\mathrm{cd}}$ & $73.6^{b c}$ & $79.6^{\mathrm{ab}}$ \\
\hline SCG & $24.7^{c}$ & $80.8^{a}$ & $70.4^{\mathrm{a}}$ & $50.5^{\mathrm{b}}$ & $30.8^{c}$ & $28.0^{\mathrm{c}}$ \\
\hline SCL & $8.3^{\mathrm{c}}$ & $16.3^{a b c}$ & $22.2^{\mathrm{a}}$ & $15.0^{a b c}$ & $20.5^{\mathrm{ab}}$ & $9.7 \mathrm{bc}$ \\
\hline $\mathrm{SCO}$ & $44.8^{b c}$ & $2.9^{\mathrm{d}}$ & $7.4^{\mathrm{d}}$ & $34.3^{\mathrm{c}}$ & $48.7^{b}$ & $62.3^{a}$ \\
\hline SCP & $22.2^{a}$ & $0.0^{\mathrm{b}}$ & $0.0^{\mathrm{b}}$ & $0.2^{\mathrm{b}}$ & $0.0^{\mathrm{b}}$ & $0.0^{\mathrm{b}}$ \\
\hline PV & $8^{c}$ & $44^{\text {a }}$ & $39^{\text {a }}$ & $35^{\mathrm{ab}}$ & $32 \mathrm{ab}$ & $25^{b}$ \\
\hline
\end{tabular}
legumes (SCL), other species (SCO), bracken fern (SCP) and of pastoral value (PV).

Means with different superscripts within a row are significantly different $(P<0.001)$. 


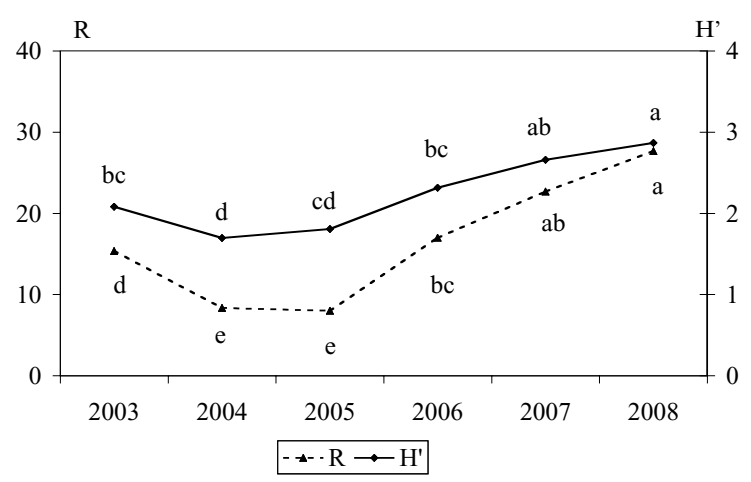

Figure 1. Shannon-Wiener index ( $\left.\mathrm{H}^{\prime}\right)$ and floristic richness ( $R$, number of species occurring on a transect) during the period 2003-2008. Values for each parameter with the same letter are not significantly different at $P<0.001$.

Figure 1 shows the trends along the years of biodiversity, as measured by the Shannon-Weiner index ( $\left.\mathrm{H}^{\prime}\right)$, and of floristic richness (R), reported as average number of species occurring on a botanical samples. Both these parameters showed a general increase after the period of maintenance cuttings, as this agronomical intervention permitted a higher presence of sown species at the beginning of the trial; after that, a remarkable increase in biodiversity and floristic richness was observed, as a consequence of the strong re-naturalisation of the studied area. This evolution was performed by native species, producing a reconstitution of a stable composition from a botanical point of view and keeping a good pastoral value which, while tending to a gradual decrease, is however interesting to wildlife.

Specific investigations were performed in order to assess the real utilisation of wild animals on occurring species of the restored pasture. Figure 2 shows the evolution, in the observed area, of the general animal intake of the pasture, expressed as the value of the total species eaten by ungulates during the summer months, measured by the index of defoliation rate (DR). Generally, the decrease of pastoral value expresses a low quality of pasture and thus results in a loss of utilisation by animal grazing. This open area has shown a decrease in the pastoral value, but not a parallel decrease in the presence of ungulate users, and this demonstrates a general appreciation by wild animals even when the area was dominated by native species in the last period of the observation. Thanks to data

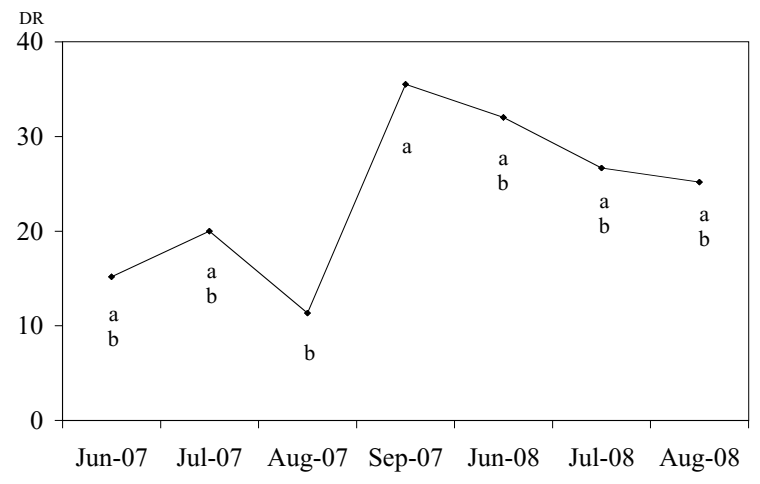

Figure 2. Trend of defoliation rate (DR) during the summer months (2007-2008). Values with the same letter are not significantly different at $P<0.001$.

on the defoliation rate, recorded during the summer months since June 2007, a significant and constant utilisation of the present species has been observed. The higher value found in September 2007 is referred to the increased utilization of recovered pasture during the highlight of the red deer mating season, as this area is historically used by males for mating rituals. Unfortunately it was not possible to verify such a hypothesis based on the values of DR in September 2008, as in August the area was unexpectedly subjected to a mowing which made it impossible to implement the observations previously taken.

The methodology carried out permitted the analysis of animal grazing on single taxa occurring along the transect. Figure 3 shows the trend of the browsing effect on some of the most consumed herbaceous species by the wild ungulates in the last two years of observation. Data is reported as a ratio between DR of the species and its percentage presence in the canopy (SC). All the botanical species represented in the graph have got a specific index equal to zero, but they were constantly consumed in the months taken into account from 2007 to 2008. Some species, as Galium cruciata (L.) Scop. and Viola tricolor L., were constantly consumed in the summer months, whereas other ones, such as Hypericum perforatum L. or Teucrium scorodonia L., presented remarkable differences in grazing in the same period. These differences could depend on the irregularity of the nearby forage availability. Data confirms the lack of relationship between specific indexes (generally established for 


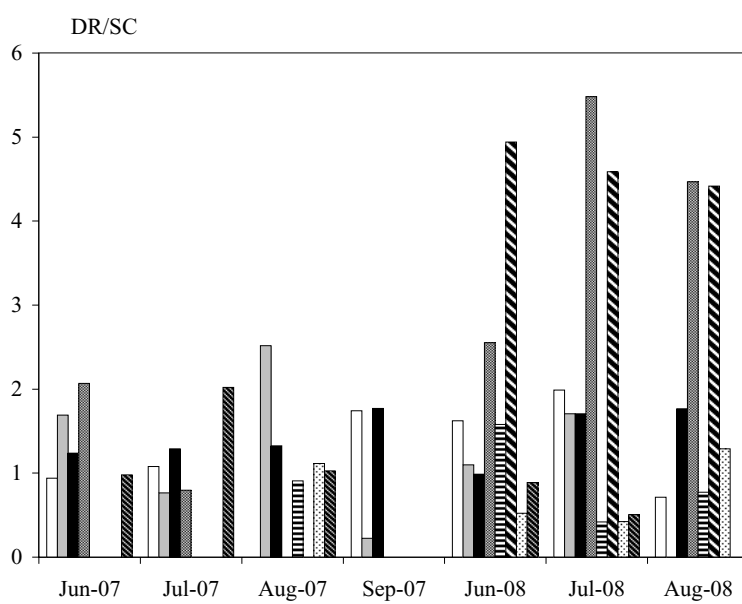

domestic animals) used for calculating pastoral value and the real consumption by wild animals, that also choose species considered of no forage interest for domestic species.

\section{Conclusions}

The obtained results confirmed the efficiency of the habitat improvements in terms both of forage quality and biodiversity of the pasture in the studied area. The effects of agronomical managements have shown that the restoration operated by mowing, ploughing and sowing with a suitable seed mixture is very effective in reducing the bracken fern infestation and in the recovery of a pasture interesting as a food resource for wild ungulates. The preservation of the restored pastoral resources through forage cutting seems to be essential in order to reduce the presence of bracken fern and to maintain the sown species, whose presence was strongly affected by the removal of vegetation. Moreover, the method used to measure the defoliation rate gave effective indications concerning the real consumption of several species by ungulates. This study highlighted the peculiarity of feeding preferences of wild animals while grazing. The wild animals present in the study area chose the native species which re-colonised the restored pasture in a different way from domestic livestock. Thus, the pastoral value of a pasture area utilised exclusively by wild ungulates, calculated using the specific indexes elaborated for domestic animals, can lead to mis- $\square$ Cytisus scoparius

$\square$ Galium album

- Galium cruciata

$\square$ Hypericum perforatum

目 Ranunculus acris

$\mathbf{\Delta}$ Teucrium scorodonia

Veronica chamaedrys

Viola tricolor
Figure 3. Utilization rate (DR/SC) of species grazed by wild ungulates during the summer months (2007-2008):

$\mathrm{DR} / \mathrm{SC}<1$ : species very little used in comparison to availability or even rejected;

$\mathrm{DR} / \mathrm{SC}=1$ : species consumed in proportion to presence in the pasture;

$\mathrm{DR} / \mathrm{SC}>1$ : selected species.

leading conclusions about the real forage potentiality of the area.

For these reasons, further investigations should be encouraged, in order to assess in a proper way the specific indexes for the evaluation of the pastoral value for faunistic purposes.

\section{References}

Argenti G., Sabatini S., Staglianò N., Talamucci P. 2000. Vegetazione prato-pascoliva infraforestale e biodiversità di un'area alpina orientale. In: Bucci G., Minotta G., Borghetti M. (eds.): Proceedings of $2^{\text {nd }}$ Congress of SISEF, 20-22 October 1999, Bologna, Italy, 267-272.

Cavallero A., Rivoira G., Talamucci P. 2002. Pascoli. In: Baldoni R., Giardini L. (eds.): Coltivazioni erbacee. Foraggere e tappeti erbosi, 239-294. Pàtron Editore Bologna.

Cervasio F., Di Leo V., Ponzetta M.P., Argenti G., Genghini M., Sacconi F. 2008. Efficiency of environmental improvements in open areas of the Central Apennine Mountains (Italy). Grassland Science in Europe, vol. 13:87-89.

Cervasio F. 2009. Recupero e valorizzazione della potenzialità pabulare di aree aperte in zone collinari e montane dell'Appennino. PhD Thesis, University of Florence, Florence.

Daget P., Poissonet Y. 1969. Analyse phytologique des prairies. Applications agronomiques. Doc. 48, CNRSCEPE. Montpellier.

Danilkin A., 1996. Behavioural ecology of Siberian and European roe deer. Chapman and Hall, London.

Didier L. 2001. Invasion patterns of European larch and Swiss stone pine in subalpine pastures in the French Alps. Forest Ecology and Management, 145:67-77.

Dzwonko Z., Loster S. 2007. A functional analysis of veg- 
etation dynamics in abandoned and restored limestone grasslands. Journal of Vegetation Science, 18:203-212.

Jouglèe J.P., Dorèe A. 1987. Le pasturage mixte ovinèquin, rapport d'ètude. CEMAGREF-INFERM, Grenoble.

Laiolo P., Pondero F., Ciliento E., Rolando A. 2004. Consequences of pastoral abandonment for the structure and diversity of the alpine avifauna. Journal of Applied Ecology, 41:294-304.

Le Duc M.G., Pakeman R.J., Marrs R.H. 2000. Vegetation development on upland and marginal land treated with herbicide. for bracken (Pteridium aquilinum) control in Great Britain. Journal Environmental Management, 58:147-160.

Lombardi G., Reyneri A., Cavallero A., Argenti G., Sabatini S., Staglianò N., Talamucci P. 2001. La gestione conservativa delle superfici pastorali dell'arco alpino. Contributi alla conoscenza scientifica, P.F. MiPAF "Gestione delle risorse prato-pascolive alpine", $7-15$.

Lombardi G. 2005. Optimum management and quality pastures for sheep and goat in mountain areas. Options méditerranéennes, n. 67, 19-29.

Magurran A.E. 2004. Measuring biological diversity. Blackwell Publishing, Malden.

Mayer A.C., Stockli V., Konold W., Kreuzer M. 2006. Influence of cattle stocking rate on browsing of Norway spruce in subalpine wood pastures. Agroforestry Systems, 66:143-149.

Messeri A., Staglianò N., Pazzi G., Targetti S. 2007. Management effect on phytomass and litter in seminatural grasslands. Procedings of $14^{\text {th }}$ Meeting FAO-CIHEAM Mountain Pastures Network, 30 May-1-June 2007, Troyan, Bulgaria, 207-215.

Orth D., Carrère P., Lefèvre A., Duquet P., Michelin Y., Josien E., L'Homme G. 1998. L'adjonction de chevaux aux bovines en conditions de sous-chargement mod- ifie-t-elle l'utilisation de la resource herbageère? Fourrages, 153:125-138.

Ouden J. den 2000. The role of bracken (Pteridium aquilinum) in forest dynamics. $\mathrm{PhD}$ Thesis, Wageningen University, Wageningen.

Pain D.J., Dixon J. 1997. Why farming and birds in Europe? Farming and Birds in Europe. In: Pain D.J., Pienkowski M.W. (eds): Farming and Birds in Europe, 1-24. Academic Press, London.

Pakeman R.J., Marrs R.H. 1992. Bracken control vegetation restoration and land management. Biological Conservation, 62:101-114.

Peeters A. 2008. Challenges for grasslands, grasslandbased systems and their production potential in Europe. Grassland Science in Europe, vol. 13:9-24.

Roggero P.P., Bagella S., Farina R. 2002. Un archivio dati di Indici specifici per la valutazione integrata del valore pastorale. Rivista di Agronomia, 36:149-156.

Rook A.J., Tallowin J.R.B. 2003. Grazing and pasture management for biodiversity benefit. Animal Research, 52:181-189.

SAS 2003. SAS/STAT software, release 9.1 SAS Institute Inc., Cary, NC.

Silver W.L., Ostertag R., Lugo A.E. 2000. The potential for carbon sequestration through reforestation of abandoned tropical agricultural and pasture lands. Restoration Ecology, 8:394-407.

Staglianò N., Argenti G., Pardini A., Bianchetto E. 2003. Influence of shrubby vegetation on biodiversity in a pasture of the Apennines (Central Italy). Grassland Science in Europe, vol. 8:580-583.

Van den Pol-van Dasselaar A., Vellinga T.V., Johansen A., Kennedy E. 2008. To graze or not to graze, that's the question. Grassland Science in Europe, vol. 13:706-716.

Zarovali M.P., Yiakoulaki M.D., Papanastasis V.P. 2007. Effects of shrub encroachment on herbage production and nutritive value in semi-arid Mediterranean grasslands. Grass and Forage Science, 62:355-363. 